\title{
Analysis of Officials' Livestreaming Sales of Agricultural Products
}

\author{
Zeng Sishi ${ }^{1, a^{*}}$, He Jiaqi ${ }^{2, b}$ \\ ${ }^{1}$ Department of Public Administration, Nanfang College of Sun Yat-sen University, Guangzhou, Guangdong, 510000, \\ China \\ ${ }^{2}$ Department of Public Administration, Nanfang College of Sun Yat-sen University, Guangzhou, Guangdong, 510000 , \\ China \\ *Corresponding author. Email: 251135392@qq.com
}

\begin{abstract}
In recent years, with the rapid development of the Internet economy, online livestream E-commerce became quite popular. To get rid of poverty, the government report points out that it is important to carry out "Internet+Poverty Reduction" Mode. Many officials become livestreaming celebrities to represent their countryside and help the farmers to sell local goods, especially the agricultural goods. With the local officials' pitching into the work, many goods sell better than before. To push forward the effect of livestream E-commerce, to realize the value of local officials' livestream E-commerce and to help the strategy of getting rid of poverty, this thesis analyzes this phenomenon, points out the related problems and gives some suggestions.
\end{abstract}

Keywords: consumption helps farmers, get rid of poverty, Livestreaming Economy, Officials' Livestream E-commerce, livestreaming celebrities, poverty reduction, rural revitalization

\section{BACKGROUND OF THE RESEARCH}

\subsection{National Policies}

In 2018, Guiding Opinions of the Central Committee of the Communist Party of China and the State Council on the Three-year Action of Winning the Battle against Poverty was released. It pointed out that we should deeply implement the action of network poverty reduction and innovate the mode of "Internet+Poverty Reduction". In 2019, the general office of the CPC Central Committee and the State Council issued the Strategic Outline of Digital Rural Development, emphasizing that digital countryside is not only the strategic direction of rural revitalization, but also the important content of building digital China. Driven by the national macro strategy, revitalizing the local economy through "Internet + " and "Intelligence + " and accelerating poverty reduction through digital construction have become an important measure for the innovative development of governments at all levels. livestreaming sales, as a new way of E-marketing, is also thriving.

\subsection{The Rise of the Livestreaming Platform}

With the development of Internet technology, as well as the high popularity of smart phones, livestreaming technology develops soon. Since 2016, with the push of the Internet tycoons such as Taobao, KuaiShou and TikTok and the venture capitals, livestreaming start-ups emerge in large numbers. China's livestreaming industry has entered a new stage of rapid development. In 2019, when the first year of livestreaming sales came, livestreaming sales has become the biggest focus to confirm the profits of E-commerce platform. The performance of realizing profit of livestream is amazing, and the consumption mode of livestream is gradually formed.

\section{REAL CASES}

The central government has repeatedly stressed the role of Internet in poverty alleviation, so that the agricultural products can be consumed out of the countryside through the Internet. In April 20th, General Secretary Xi Jinping came to Jinmi Village, Xiaoling Town, Zhashui County, Shangluo City, Shaanxi Province, and went to the livestream platform of the training center of the village. At that time, Li Xuying was preparing to broadcast on the livestreaming platform. The arrival of the General Secretary made her a Internet Celebrity. Most of the local specialties sold by Li Xuying are from the poor. Li Xuying told reporters, I'm more motivated to sell for the poor because there is more responsibility in it. To consume for poverty alleviation, netizens are also motivated. During the livestream, the products promoted by $\mathrm{Li}$ Xuying were often sold out. It is becoming a trend to carry goods on livestreaming platforms and to consume for supporting the 
poor. The unsalable goods have become the best-selling goods, and the little-known mountain goods have become the online "hot-sale goods". The poor's frowns have been stretched and the road to poverty alleviation has been widened.

On Tiktok and KuaiShou, there is a trend of Officials' livestreaming sales. Lv Xingdian, deputy mayor of Huainan Town, pan Kwai District, was also following the trend. He used new media to find a way out for local agricultural products, and he worked hard to sell goods in Kuaishou livestreaming platform, letting people know their local goods, and popularizing the goods of the poor farmers.

In addition, the COVID-19 epidemic has brought a huge impact on the national economy. The unsalable situation of agricultural products pushed officials all over the country to meet the difficulties and take the advantage of livestreaming sales. It is well appraised to take advantage of this new media to find a way out for selling the agricultural products. It can be said that both crisis and opportunity exist. The livestreaming sales of officials is not only a solution to the problem of unsalable products during the COVID-19 epidemic period, but also an opportunity for the normalization of "Internet + government + agriculture" in the future, which provides a new way for all regions to promote poverty alleviation and rural revitalization.

The live broadcast of agricultural products by grass-roots officials has injected new force into the new media publicity. By using the public trust of the government to promote the local agricultural products, on one hand, people feel new which can attract more audiences, expand the publicity, and accumulate more popularity. On the other hand, it is more persuasive, and it is an official guarantee for the quality of agricultural products, which makes people trust more.

\section{ANALYSIS OF LIVESTREAMING E-COMMERCE BY OFFICIALS}

\subsection{Advantages}

First, the county magistrate's livestreaming sales of the products does not only open the market for agricultural products, but also popularizes the brand of agricultural products. The officials' livestreaming sales of local agricultural products spreads rapidly over the country through the news effect, and increases the public's attention soon.

Second, the officials' livestreaming sales conforms to the trend, and this way is very down-to-earth. The period of commodity promotion can be shortened as much as possible through livestreaming sales. Livestreaming Sales of Goods can effectively reduce the traffic cost, making the products sold at the most favorable price, which is undoubtedly conducive to the promotion of agricultural products.
Third, the county magistrate's participation in livestreaming sales of goods can make agricultural products more easily recognized by consumers. As the representative of the county, the county magistrate's identity has the credibility to speak for the local agricultural products, which can enhance the consumer's trust in the local agricultural products and help the farmers to better sell the agricultural products, but also has a certain appeal and scale.

\subsection{Disadvantages}

First, livestreaming is real-time. As a county magistrate, he is not professional in this industry. He may not be able to ensure that everything is safe for many emergencies. Once there is improper speech or behavior, it is likely to be magnified by netizens, which will affect personal image.

Second, it's new and with strong explosiveness, but with weak sustainability. The interest of netizens is changing rapidly, and the hot spots are likely to subside soon. Therefore, how to change the freshness of livestreaming into sustainable and long-term freshness of this industry also requires county leaders to pay attention to consolidating the foundation of agricultural industry development, vigorously develop new agricultural products with excellent geographical names, and drive more farmers to join the livestreaming platforms, so that farmers can live the whole process of agricultural products from planting to selling, attracting more customers.

\section{SUGGESTIONS}

For livestreaming sales of agricultural products, we need to pay attention to meet some conditions, not to sell for show, but to carry out strategically. The products to sell in the livestreaming platforms need to have qualifications as follows:

First, it has its own online sales channel. Through livestreaming sales, it can be linked to Taobao store or some other online sales channels for sales.

Second, the products should be ready for promotion. In addition to open online stores and online sales channels, they also need to have their own brands, packaging, pricing for target groups, etc.

Third, since there are a lot of report and news, we must focus on the promotion of the brand instead of the product itself. Both the livestreaming celebrities and the news need to redraw the brand. This can help to improve the brand's visibility.

Fourth, consumption helps agriculture is sustainable, not short-term. Livestreaming sales is a long-term work, not a periodic outbreak, not a flash in the pan, which needs long-term efforts. At present, some places are doing livestreaming training. Local governments teach enterprises how to use new media and new consumption methods to attract customers and promote sales. 
Fifthly, it's a professional and continuous work to build Internet Hot IP, not an instant news event.

Sixth, the promotion of livestreaming sales of goods should aim at target customers accurately.

\section{CONCLUSION}

Leading officials to sell good on livestreaming platforms, to make unsalable become best-selling, embodies the practical style of the officials who have responsibility and innovative ideas of keeping pace with the times. The achievements presented are worthy of affirmation and the accumulated experience is worthy of promotion. The branding of agricultural products is an important driving force of Rural Revitalization Strategy. The direct impact of the county magistrate's livestreaming sales is to promote the development of branding, which is conducive to the improvement of the quality and added-value of agricultural products. But at the same time, we should never regard officials' livestreaming sales of products as a show. Only when we solve problems for the masses and increase their well-being in the livestreaming, can we innovate and lead the poor to get rid of poverty and become rich together, which is the key for the officials to truly work for the welfare of the people.

\section{REFERENCES}

[1] Wu,Z.J., what's the fire in the live broadcast of the county magistrate, Chinese brand, 2020 (5), 60-61

[2] Shi,H.C., live delivery, Guangcai, December 2019, 24-29

[3] Xu,F., the "cold" thinking behind the "hot" live broadcast by the county magistrate, news outpost 2020 (3), 19-20

[4] Guo,L., county magistrate how to go further with live delivery, well off, 2020 (15), 47-49

[5] Meng,W., can official live broadcast "keep fresh", people's forum, 2020 (z2), 52-54

[6] Yu,J.Y., live broadcast with goods, county magistrate coming, Xiaokang, 2020 (15), 24-28 